\title{
Agro-Enterprise Development to Support Women Groups in Poultry Production and Marketing: A Case Study of Central River Region of the Gambia
}

\author{
Saikou E. Sanyang \\ Department of Agriculture, Regional Agricultural Directorate of North Bank Region, Kerewan, Gambia \\ Email:saikoue@gmail.com
}

Received August 31, 2012; revised October 8, 2012; accepted October 23, 2012

\begin{abstract}
In the Gambia, the agricultural sector contributes $33 \%$ to GDP, and $85 \%$ of the labor force are engaged in agricultural activities including crop and livestock production. The method of data collection for this research was non-probability using judgmental sampling. A total of nine organized women groups engaged in poultry production as income generating activity were interviewed face-to-face using structured questionnaire. The target respondents were 150 and out of the number $85 \%$ of the questionnaires were received. For data analysis simple descriptive statistical techniques like percentages, regression correlation, Chi-square, Kruskal Wallis $\mathrm{H}$ and Mann Whitney were used. Basically, the objectives of this research work are assessing the income level, training needs and problems of women poultry producers. In terms of age distribution result shows that, majority poultry producers were in the age group of $31-40$ years $(44.5 \%)$ and 20 - 30 years $(24.2 \%)$. However, the result reveals agro-producers were in the age greater than 50 years $(7.8 \%)$, meaning that, there are no age restrictions for women groups who want to start business. The research reveals that Boiram women group scored a total profit of US\$ 1417 while the lowest profit of US\$ 939 scored by Brikamaba respectively. The research finding proves that, the highest price offered for a broiler is US\$ 5.79 while lowest price offered at US\$ 3.84. Furthermore, 50\% of the women respondents in the study site indicate group management and marketing skills as major training needs. Base on addressing the objectives of this research findings like assessing the income, training needs and problem solving we conclude that poultry production enterprise plays a meaningful role in poverty reduction, generate income, and create employment opportunities in improving the living standard of women and enhancing the growth of local economy.
\end{abstract}

Keywords: Agro-Enterprise; Income Generating; Women Groups; Poultry Production; Gambia

\section{Introduction}

The agricultural sector of the Gambia plays an important role as food provider, employer, and foreign exchange earner. The women farmers engaged in agro-enterprise activity of fruits and vegetables production has become a prominent potential in The Gambia farming systems. The production of fruits and vegetables forms the greatest share for the provision of additional food, foreign exchange earner, and source of income for women engaged in horticultural production. As women constitute half of the population can be a great resource in the development process, if they are properly mobilized and organized. The government of the Gambia is putting more emphasis on the economic advancement of women. Notably, the government is responsible for planning and implementing women's development programs and formulating gender-specific policies giving them priority in institu- tional forum. Moreover, traditional poultry production system is extensive in nature characterized by rearing of small flocks, which are owned and managed by women and children for nutritional requirement. Apart from the traditional poultry production, small-scale commercial poultry farms are also located in the Peri-urban areas producing broilers and table eggs. Livestock production is important to the economic growth of developing countries like the Gambia, a contribution that can go beyond direct food production including multipurpose products such as feathers and manure. It further serves as good source of income and barter product in societies where there is no accumulation of capital.

Further, linked to the religious and socio-cultural lives of several million resources poor farmers for whom animal ownership ensures varying degrees of sustainable farming [1]. The women producers have under taken poultry production as an agro-enterprise activity for in- 
come generating activity. Poultry production enterprise is a potential area for women groups to harness income, job create opportunities, improve quality life and standard of living for women residing in rural communities of The Gambia. According to [2] agro-enterprise refers to a business activity, typically on a small-scale either on farm or off-farm. Primarily, this research work focuses on poultry production and marketing in enhancing the income generation activity of women's groups in central River Region.

The rationale of choosing poultry production as an income generation is because of short generation intervals, and high turnover rates on investment compare to other livestock like sheep, goat and cattle. Poultry can also serve as a protein source from meat and egg for rural community of The Gambia. Secondly, the women groups in the study have certain characteristics as organized groups, diverse ethnicity, different age groups, illiterates and paucity knowledge in poultry production techniques. Basing on these reasons actually motivated the author to research on poultry production and marketing supporting rural women in The Gambia. This is of great importance, because the economic development of nations relates to the advancement of women in the third world countries [3]. As a result, demand for poultry meat in urban areas, it is therefore important to promote poultry production through the support of the governments, NGOs and privates sectors, to increase income, reduce poverty and be self-sufficient in house hold food security. Women in the central region of the Gambia are facing problems, less accessible to land, credit facilities, markets, agricultural inputs, inappropriate technologies, related business management and group management skills, capacity building, limited access to finance, and information all affecting poultry production as agro-enterprise for income generating activity.

Therefore, for these women groups to be successful in the future they need managerial skills to enhance their business potentials. The participation of women groups can enhance poultry production for income generation in rural areas of The Gambia. [4], advocates for special attention on the needs of women, who are the predominant farmers in many developing countries. The responsibilities of rural women are increasing day-by-day for generating income and assuring maintenance of their families. International donor agencies and NGOs prefer to work with organized groups than individual farmers because it gains considerable dividends in terms of assessing new information, credit, low-cost inputs, cohesiveness, sharing of ideas, and re-payment of loans [5]. The idea of integrated rural development includes growth in agricultural production, processing, marketing and creation of employment opportunities for rural farmers [6]. Women groups are committed to development programs immedi- ate changes can come through group participation rather than individuals. Thirdly, for the issue of training and dissemination of information would be much easier when farmers are well organized to engage in poultry production. Organizing women into groups is an effective way of learning new ideas to be become more competitive and gain economic of scales [7].

Furthermore, development agencies are increasing their emphasis on assisting women to secure income through their own efforts. Such approaches are categorized as "income generating activities" and cover initiatives as diverse as small business promotion, cooperative undertakings, job creation schemes, credit and saving groups and youth training programmes. It is sometimes argue that education, and health provision, legal and political changes, and global economic all affect the abilities of women to secure an income. However, group management are more demanding in terms of resource mobilization, time consuming, disagreement on issues, conflicts but the advantages outweigh the disadvantages. This research work consider income generating activities as initiatives that can bring rapid changes in the socioeconomic development of women through the use of tools such as agro-enterprise activities, credit and saving and business management.

\section{Literature Review}

There were many studies conducted on agro-entrepreneurship, micro, small and medium enterprise in a global perspective. The success of poultry production enterprises would depend on sound business culture, education, and dexterity among others. This research work focuses on agro-enterprise approach that would support women groups engaged in poultry production. The rationale of agro-enterprise development as a research topic is basically to meet up the challenges of food and nutritional in-security, income security, and poverty alleviation. Hence, to meet the challenges of food security, income security and poverty alleviation, women would need support in order to participate effectively and efficiently in poultry production through the process of value-addition.

\subsection{Agro-Enterprise Development}

This approach is an important tool that can be used to attain food security, income security, and poverty alleviation in developing countries. The role of women in national or rural development cannot be underestimated for sustainable economic growth and development. From literature reviews women are at the core of development activities. The role of agro-enterprise or small and medium enterprises in poverty alleviation has long been recognized as vital, and promotion of small and micro- 
enterprises for women has been realized as a key factor augmenting family welfare [8]. Investments in agro-enterprise for income generating activity are important and a step in the right direction to uplift the lives of rural communities. Rising productive base or capacity can improve rural income and reduce food price and make food accessible for rural women to make ends meet. Agro-enterprise for income generating activities focuses on groups at producer level and individual actors that provide services within the group, [9]. Aagro-enterprise development as income generating activity have problems associated with marketing and setting up of new organizational structures poses serious challenges to poor farming communities particularly those accustomed to produce only basic staple food for household uses. This approach was developed in response to demand from partners in agricultural development who want systematic method shifting from a food security strategy that focused on production to a market-oriented approach that emphasizes profit, income and market demand [10]. Agro- enterprise can be located in rural or urban areas on micro or small scale, domestic or foreign, public or private. These can be corporations, cooperatives, family-based entities or single proprietorship hence governed by set of rules. The agro-enterprise approach is singularly non-commodity specific and support collective action, diversification and value addition as pathway for poverty reduction. This approach can be adapted to support the specific needs of women groups and address the needs of vulnerable groups such as youths, old age, and women. [11] Entrepreneurial activities in rural areas are based on agricultural and natural resource products, farm families to broaden their income strategies by including value chain-operations [12]. Thus market-oriented enterprise diversification occurs both on farm and off farm, within the same household and amongst small and medium scale off farm rural agro-enterprise. In Bangladesh, women in rural areas were involved in agro-enterprises like poultry rearing, sale of eggs, broilers, and chicks, goat and sheep fattening, cattle rearing are common agro-enterprise occupations [13]. For income-generating activities, like producing poultry and selling of products would enable women to improve on their income. An agro-enterprise not only enhances national productivity, generate employment but help to develop economic independence, personal and social capabilities among rural women [14]. The goal of agro-enterprise is to improve management skills, and competencies, increase profitability, competitiveness and enhance household income.

Therefore, rural agro-enterprise approach will continue to play a supporting role in improving the household economy, using profits to meet household basic necessities and amusements. The creation of small enterprises in rural communities can contribute to rural economy hav- ing multiplier effect on the local economy. This means that, the purchase of goods and services by the local people will go directly or indirectly as stimuli to local economy. In Vietnam, according to literature agro-enterprise activity works within remote tribes in hillside areas, in an attempt to introduce more commercial approach to development work. The level of commercial engagement varies considerably across the farming groups and where projects evaluate the ability of these different groups to tackle increasing level of risk. Furthermore, agro-enterprise activity for income generating activities would be more meaningful when programmes are directed to organized groups working in tandem with service provider. Farmer groups and business development service providers are the basic units of change where actors will enhance marketing process for delivery of goods to markets. Moreover, there is growing consensus that, if smallholder farmers in developing countries to succeed in a competitive marketplace they need to be well organized in productive activity [15]. Creating business initiatives would be one way of level playing field, providing an opportunity to achieve economic equality and generate higher income for women groups. [16], Earmark the importance of agro-enterprise for rural development indicating that success in agro-enterprise development will improve socio-economic status of household. Further went to say that, if correctly managed this approach can empower rural communities to bring about changes in living condition of women.

[17] suggests that agro-enterprises do benefits women groups from broadening their network through information dissemination and strengthening their existing relations with other actors in the supply chain. This will help women groups in respond to markets by changing or improving what they already produced, cost of production, and to realize profit more quickly [18]. Importantly agroenterprise activity furnishes crucial inputs and services to the farming sector, improving on cost competitiveness, quality and safety of its products, to help farmers integrate their activities among other farmers. In addition, agro-enterprises engaged in value-added products might also benefit from increased attractiveness of food products grown under eco-friendly management systems identified with a farm or rural community [19]. Promoting agro-enterprise and small business increasingly seen as a tool of generating meaningful and sustainable employment opportunities particularly for those at the margins of the economy such as women, the poor and people with disabilities. Micro, small and medium-sized enterprise recognized a way to promote women's economic empowerment while fighting poverty [20].

Agro-entrepreneurship generally identified as engines of economic growth by many governments, and their promotion adopted as a development strategy by many 
institutional and regional players to create new jobs for developing countries to drive innovation and economic dynamism. Economic empowerment has shown positive impact on women's self-confidence, negotiating position within the household and involvement of women in decision-making processes [21]. Agro-enterprise and other small businesses offer strong benefits for rural development approaches. Providing effective support for women businesses is crucial for promoting women agro-enterprises. Cooperative ventures and community based business can improve wages, working conditions, fostered greater participation in management skills [22].

\subsection{Women Participation in Poultry Production}

Women participation in agro-enterprise activities such as poultry production is much more than what statistics revealed. This is mainly due to the fact that most of the work done by women at farm and home is disguised as daily activities. Women groups having pool of their resources to take up an enterprise need innovative mind and motivation [23]. Agro-enterprise development related to poultry production and management is a vital tool in income generation for women entrepreneurs in The Gambia. In this form of agro-enterprise, major shares of the work handle by women performance on poultry production and management operations. Moreover, livelihood improvement would need the participation of women groups in the rural communities by designing development projects and programmes that would serve as a source of income generation such as poultry production. These are all potential areas that can support women to bring about positive change to their livelihood.

On one hand the issue of land is a prerequisite for agro-enterprise promotion in income generating activities for women groups in rural areas of most developing countries. Lack of land for farming is severest constraints faced by rural communities, and affects more women than men. The [24] indicate that women generally have limited access to land, because they are not recognized as beneficiaries in terms of land acquisition. Notably land is a critical issue and land crabbing is escalating in many developing countries where land is purchased or leased by developed countries. For example International Fund for Agricultural Development (IFAD) for women groups with little or no land provides strong support for nonfarming activities, such as marketing, processing and other micro-enterprises. According to [25] as women are emerging sector in global business environment, support from NGOs, governments, and private sectors are potentially important means of raising the level of entrepreneurship in a society. In view of this, the support of women should be centered on encouraging, and assisting relevant business initiatives, financial assistance, information, education, and networking structures. Moreover, effective networking that aims to inform women groups for income generating activities about government policies may have secondary benefits in terms of encouraging business women. Given the potentials of women in income generating activities, there is a need to introduce specific measures to enable women groups to communicate with their counterparts in the same locality. In literature, many NGOs have taken on the task of women empowerment through agro-enterprise and or microenterprise in recognition of change it can have on women and their families.

On one hand, donor agencies, and NGOs realized that organizational networking among women group cannot be sustainable without economic improvement. Furthermore, economic improvement is only possible by encouraging and motivating the women groups through the provision of inputs, credit facilities, cultivable land, and access to markets. This will serve as a catalyst in their income generation. Women equally endowed with motivation and managerial capabilities in starting and running small enterprises located in their own homes or communities. Promoting and developing such entrepreneurship among rural women will require premise, encouragement and motivation from the development agencies [26]. More awareness, motivation and knowledge about women groups' formation as an option to conduct business, are widely needed by women entrepreneurs mostly to benefit.

Moreover, higher participation of women in family decision making process helps women to have greater say in family resource allocation matters. Through this process, they can exercise their control on use or misuse of resources within the family. Therefore, any economic development program targeted for women groups should have impact on their level of participation in decision making [27]. The ability of women to generate income also depends on the extent to which they participate in the decision-making process at all levels, including the highest national levels. However, the overall women groups hold an extremely low number of decision-making positions in local communities dealing with agriculture and rural development. The success of any enterprise serving as income generating activities for women groups or organizations would entirely depend on training for sound economic growth and development [28].

Training is the engine of economic growth and development for women entrepreneurs engaged in business activities. Education and training enhances economic and employment opportunities in the non-farm sector by providing the rural poor with marketing skills over and above their labor [29]. To enable rural people to diversify into non-farm income-generating activities, the government of The Gambia needs to provide appropriate tech- 
nologies, managerial service and skills training for women organizations that would promote income generation in rural areas. One aspect will be training to impetus contributions of agricultural research and development institutions. [30] indicate that many African countries undertake income generating activities in order to sustain their families and have some extra income for emergency. Some women would prefer to run their economic activities as individual and other organized groups. The need for income is becoming a pressing need day by day. There is need to build the capacity of women groups in entrepreneurship, and management skills. The donor agencies and NGOs providing support to women groups are contributing and playing an important role by providing institutional support through the creation of self help groups, micro-enterprise at village level, formation of women cooperatives, and designing training programmes to build on their capacity [31]. For there to be efficient productivity, profitability, and sustainability training programmes should be in tandem with production and business management skills.

\subsection{Poultry Production for Income Generation}

The recognition of women contribution to rural society is fundamental to agriculture and rural development in developing countries with particular reference to the Gambia. The economic role of Gambian women entrepreneurs in agricultural development would be the promotion of agro-enterprise as a pathway in income generating activities for productive groups. The idea of income generating can be farm and non-farm activities to address the issue of poverty at rural communities. Income generation through micro credit programmes has been acknowledged as it allowed the poor to be more self reliant and substantially encouraged women to engage in economically productive activities [32]. Income generating activity can empower women by enabling them to make economic decision. It has also been experienced by different researchers that empowerment of women brings significant improvement in household decision making process. Therefore, this research work will examine the salient factors such as credit and savings, poultry production, and constraints affecting the women groups in their wake of income generation. Rural poultry production over the years attracted some attention due to the enormous potential of increasing the output vis-à-vis the relatively low output at present. Women assisted in some cases by children, play a key role in this sector, as they are the main owners and managers of family poultry. According to [33] more than $85 \%$ of rural families in Sub-Saharan Africa keep one or more species of poultry, and more than $70 \%$ of chicken owners are women.

According to literature, rural women will continue to play a very important role in raising livestock. In most cases, they are solely responsible for goats, sheep and poultry reduction. It is important to stress that when dealing with poultry as a means of addressing poverty or income generating activities, the risks involved in starting up or improving the production need to be minimal from producer's point of view. Rural poultry production (backyard) units require very little hand feeding and provides handsome returns with minimum investment. Thus rural poultry farming not only generates income, employment opportunities to small farmers including women but also brings about improvement necessary to uplift the life of rural communities [34]. Many women groups are already engaged in small-scale income generating activities, like farming, food-processing, trading, and many would like to be entrepreneurs but lack capital, business skills or access to markets [35]. Non-governmental organizations (NGOs) can help by providing loans, training, give technical advice and link them to other organizations. Often, support to income-generating activities is part of a wider programme aiming at tackling a range of problems identified by women, such as housing, water supply, social care, civic education and advocacy. The participation of women in rural poultry improvement programs contributes to human development assisting rural women to acquire knowledge, so as to increase production efficiency [36]. For women groups engaged in poultry production to be economically sustainable, an enabling economic environment needs to be established. The organization of the poultry production divided into a production line, supply line and or more service line. The major challenges facing poultry production at rural communities rely on cohesive organizational structure, not technical aspects. On the other hand, creating market for poultry products is one of the few opportunities women groups can generate income. Understanding the market structure and functions is a prerequisite for developing market opportunities for rural households. Informing policy makers and development workers, considering the commercial and institutional environment in which village poultry keepers, mostly women have been operating [37]. In rural communities, market comprises of weekly markets where itinerant traders bring birds collected from villages. In addition, marketing channel for the commercial poultry sector at village level is producer to consumers and/or producer to middlemen. In addition, for the weekly market the channel is producer to consumers or producer to middlemen, producer to middlemen to consumers and producer to retailers to consumers.

However, this research work only focuses on production and marketing not the whole value chain. The future research work will examine the whole value chain of production, processing, and human resource management. Access to markets is considered as an important factor in 
poultry production. Market accessibility affects the price of the product and transaction costs influenced by infrastructure and information. Generally, for poorer households and distance, market access is low [38]. The role of women groups is not only in production activity as well as marketing is important to boost benefits from poultry keeping for poor female-headed households. If poultry marketing is well planned and managed to match the fluctuating market demand, economic benefits will shoot up. The fact that predictability of the price fluctuation is high based on socio-cultural events. In most cases, women are responsible for poultry production and selling, and spending their income on family matters. Marketing channel shortened by forming women groups to organize direct sales for poultry consumers [39]. In addition, diversification in income generating activities is also important for women's group engaged in poultry production which means that diversification has several dimensions. The rural economy is diversified, even if many non-agricultural activities are indirectly linked to agriculture. Diversified rural economy large part of the household income diversification comes from different household members each specializing in one occupation [40].

The idea of appropriate diversification process of both on-farm and off-farm can make up fluctuations in commodity prices. Diversification can make income variability greater if the various activities are affected by similar seasonal and market forces. Diversification is an important tool of increasing productivity of labour, enhancing assets and reducing risks. Linkages between country side, towns, and cities can enhance productivity and sustainability of production by generating employment, income and investment. In future, most rural area will need to look beyond agriculture and agricultural value-added production to create new sources of competitive advantage. Farm level diversification involves adding income-generating activities at the farm household level, including livestock, local non-farm, and off-farm pursuits undertaken by rural communities [41]. This will help the groups to earn a greater profit to be re-invested in to the business for sustainability.

Therefore, service provider should assist the women groups not to rely on one activity but ramify or diversify their income generating activities for better living. Another important indicator of agro-enterprise promotion for income generation in the rural communities is credit and savings. Micro-credit and savings schemes in SubSaharan Africa where Gambia is not exceptional received support from local and international institutions in recent years as means of generating income. These schemes have recognized the importance of women taking up such activities and in many cases have been successful. With proper management of credit and savings can help alleviate poverty; where loans can be used to finance sound investments with cash flow prospects allowing profit margins for repayment [42]. Credit is a financial tool for accessing inputs for production, considering the risk of being able to re-pay with low interest rate. Generally speaking, women group knows best the type of business that can earn maximum profit. Women often start by investing in livestock and then move on to other profitable activities [43]. The flow of communication and sharing of information among women groups engaged in agro-enterprise as income generating activity is a salient indicator for sustainability. The issue of information and communication technology (ICT) can improve the process of collection, analysis, and dissemination among potential buyers and sellers of agricultural products. This may shorten the time period in which purchase, inventory, and pricing decision [44]. Furthermore, the advent of mobile phones is rapidly changing the ability of communities in rural areas to communicate and gain new information.

In The Gambia, the issue of sharing information through mobile phones is surmounting between the urban dwellers and rural communities. Another means of communication or receiving information is the use of radios in rural communities. [45] indicate that, the mobile phone is considered to be the most applicable information and communication instrument and, in the future, as phones become more widely available will become an essential trading tool especially for women entrepreneurs. In supporting their ideas, women groups can use mobile telephones to verify market prices for their products and arrange transport to the market. Rural radio programmes may enable rapid sharing and dissemination of information for possible adverse effects of weather on crops. Therefore, the use of communication tools would empower the rural women to share and disseminate information reducing their transaction cost to capture the market share. The women groups would also benefit from new technology and fully participate in today's information society. The primary purpose of any enterprise is to maximize return on investment on long term basis. It is therefore; necessary to market poultry, meat products, and eggs at a price which will allow farmers especially women to maintain profitability in a competitive market. Cost effective programmes of bio-security and vaccination are required to prevent or limit the impact of disease [46].

[47], indicate that, not only should agro-enterprise development can lead to skills in income generation through building local enterprises, but would also seek to promote core values of gender equity of benefits. For community participation women's group engaged in agro-enterprise should be involved planning and implementation phase, as this will facilitate the transfer of marketing skills [48]. The level of participation should be 
practical where all the group members would have the chance or the opportunity to express her opinion during the time of group meetings. The process of holding joint meetings and planning sessions creates trust and confidence to set a clear code of practice. Therefore, working with women groups in open environment credibility will be gained and much better community participation will be achieved.

\section{Methodology}

\subsection{Study Area}

The target women groups are located in the Central River Region South of The Gambia. The region has a diverse ethnic composition consisting of Mandinkas, Fulas, Wollofs, and Sarahules. The production of rice is the predominant occupation of the inhabitants. In addition, the region has long been recognized for livestock production like cattle, sheep and goat. Moreover, improved poultry production and management has been a new intervention to women groups for income generation. This research work aimed to provide information about women poultry producers in Central Region of The Gambia. In the planning stage a preliminary pre-test was conducted to get information from the women groups engaged in poultry production enterprise. The variable measurements are in two categories nominal, and interval suitable for data analysis.

\subsection{Data Collection Procedures}

Questionnaire was designed serving as a tool for data collection. The questionnaire consists of 31 questions. This research used a wide range of question type, which includes closed ended, opened ended and multiple choice. The questions were easy and precise for the women respondents to understand in answering the questions, as they are illiterates. In designing the questions, the researcher's main goal was to maintain the interview process straightforward without ignoring the objectives of the study.

\subsection{Sampling and Sample Size}

For this research study the sampling method is nonprobability using judgmental sampling. In this case the sampling was based on experienced knowledge and professional judgment. The sampling process involves purposely identifying the women groups engaged in poultry production from the population tapping extension agents' experience and knowledge. The target population was women groups engaged in poultry production under the pilot project located in the same geographical area. The judgmental sampling method was based on these characteristics. The data collection process was face-to-face interview using semi-structured questionnaire. The survey was done by three extension agents and a supervisor using prepared survey guidelines as reference materials. The group members interviewed was the executives and other group members who possessed certain qualities. The target sample size was 150 questionnaires and 128 questionnaires were received indicating $85 \%$ of the total questionnaire.

\subsection{Data Measurement and Analysis}

The following data types used for this research work are Nominal and Interval as non-parametric data. The current research indicates non-parametric as the most suitable because the variables are free normal distribution. SPSS version 17 for data analysis like descriptive statistical techniques such as percentages, mean, and standard deviation to describe and summarize the data, Correlation, Chi-square, Kruskal Wallis and Man Whitney were used for analysis.

\section{Results and Discussion}

The issue of commercial poultry production for income generation started in Central River Region of The Gambia through the intervention of FAO in 2000. The Figure 1 shows the study areas of women groups engaged in poultry production in the Central River Central of the Gambia. The region has lots of potentials for agricultural production particularly poultry production. The approach started with individual households who were given 50 250 chicks on loan basis as a pilot project. After 5 years poultry farmers associations were formed targeting women groups who were re-organized to embark on poultry production. In terms of age distribution the result shows that $44.5 \%$ of women who are poultry producers are between the age group of $31-40$ while $24.2 \%$ are 20 - 30 years as productive groups in Figure 2. From this research we can deduce that age groups between 20 - 30 and 31 - 40 years are the productive age groups for agro-enterprise development in the rural communities of The Gambia. In categories of women groups usually the young groups are assigned with duties or responsibilities to execute. Moreover, younger age groups possess a spirit of doing something in life and have strong urge to start a business. On one hand, old age acquires less motivation and accordingly may not find stimulus package to start a new business. We have to keep in mind that old age has greater experiences, which may be regarded as one of the positive factors for entry in non-farm entrepreneurship. Old age can make the best use of their experiences earned from different fields to avoid uncertainties. In this research only $7.8 \%$ of the women entrepreneurs are $>50$ years. For older people, earning an income brings more than financial security and a chance to im- 


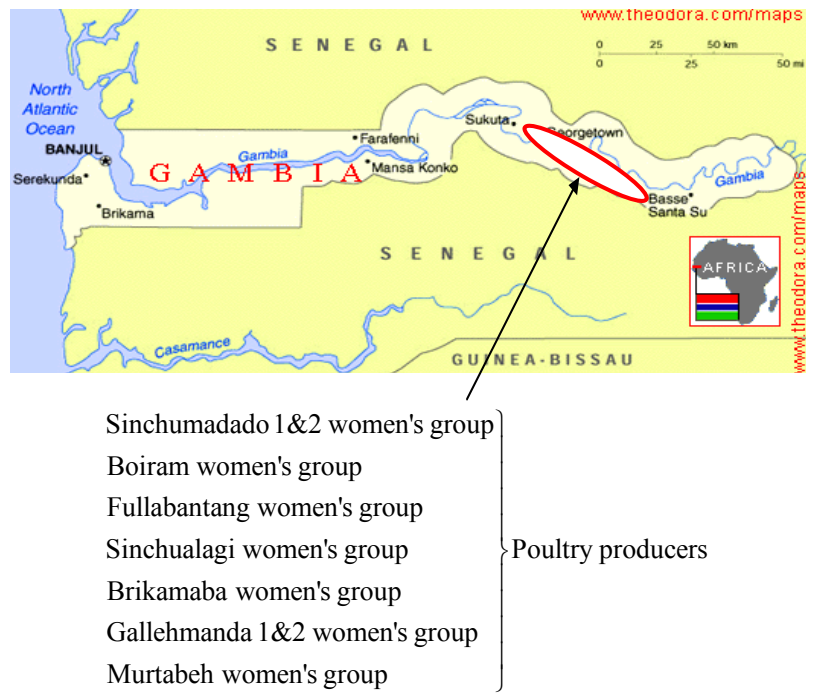

Figure 1. Map of the Gambia showing the study area.

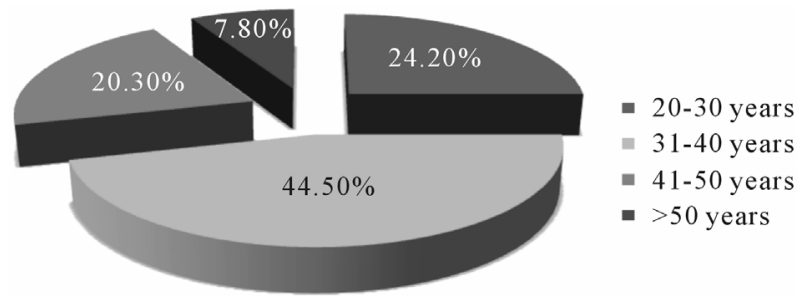

Figure 2. Age distribution of women groups.

prove their living conditions. It can also raise their self esteem; improve their status in the family and community providing valuable social contact.

A study conducted in United Arab Emirates found that most of the women entrepreneurs were generally young and were at their $20 \mathrm{~s}$ to $30 \mathrm{~s}$, and only 1 in 4 was more than 40 years [49]. Moreover, the best age for entry into innovative establishment is between 20 and 40 years. The result from this research clearly reveals that age categories are between $20-30$ and $31-40$ years. [50], most women producers premise their entrepreneurial careers between the ages of 22 and 55. Moreover, a career can be initiated before or after these years. This is not likely to happen because an entrepreneur requires experience, financial support, and high level of energy to successfully start a small business.

The issue of different age groups has been discussed in the first part of this research work. From the test result of Kruskal Wallis analysis the incomes of households were distributed significantly difference between the age groups. The square value is 13.725 with the degree of freedom 3 at significant level of 0.003 . In addition, from the table using Mann Whitney test 1 and 3,1 and 4, and 2 and 4 were significantly different at 0.05 . Therefore, it is a signal for policy makers to direct their development projects and programmes to young generation in spite of productive age group but still have low income. The policy makers should target income generating programmes between age group 1 and 3 and/or integrate both the young and old age entrepreneurs for sharing of knowledge and experiences for sustainability (Table 1).

The educational level of women entrepreneur especially developing countries received significant research attention. Some feel that entrepreneurs are less educated than the general population most particularly women entrepreneurs residing in the rural communities. In The Gambia, $73 \%$ of women are illiterates. Education whether formal or informal system is very important in upbringing women entrepreneurs in planning, organizing, directing and controlling of resources that is deem necessary to up keep a business activity [51]. The ability to deal with women groups to communicate and clearly demonstrate is important in agro enterprise development. This research result shows that, most of the women groups in the study area went through the informal system of education which is the Islamic form of education. Hence they can read and write. This is seen in all the women groups particularly Galleh Manda where $100 \%$ of women respondents attended Islamic education (Table 2). According to, [52] from their study in Northern Nigeria revealed that, $83.3 \%$ of the women respondents had Quaranic form of education.

Importantly, there are other women groups whose members obtained little form of primary and secondary education as in the case of Fullabantang and Brikamaba with $23.1 \%$ and $40 \%$ respectively. In terms of type and

Table 1. Different age group distribution and household income.

\begin{tabular}{lccc}
\hline & Age & Number & Mean rank \\
\hline & $20-30$ & 30 & $57.50^{\mathrm{a}}$ \\
$\begin{array}{c}\text { Household } \\
\text { income }\end{array}$ & $31-40$ & 58 & $60.73^{\mathrm{ab}}$ \\
& $41-50$ & 24 & $65.35^{\mathrm{bc}}$ \\
& $>50$ & 12 & $77.83^{\mathrm{c}}$ \\
\hline
\end{tabular}

Note: Mean ranks having the same letters have no significance different a $0.05(\mathrm{p}>0.05)$

Table 2. Educational level of women groups.

\begin{tabular}{ccccc}
\hline Women groups & Primary & Secondary & Arabic & None \\
\hline Sinchumadado & - & - & $53.7 \%$ & $46.3 \%$ \\
Boiram & - & $2.9 \%$ & $85.3 \%$ & $11.4 \%$ \\
Fullabantang & $23.1 \%$ & - & - & $79.9 \%$ \\
Sinchualagi & - & - & $80 \%$ & $20 \%$ \\
Brikamaba & - & $40 \%$ & - & $60 \%$ \\
Gallehmanda & - & - & $100 \%$ & - \\
Murtabeh & - & - & $80 \%$ & $20 \%$ \\
\hline
\end{tabular}


quality of education, female entrepreneurs are less privileged or disadvantaged particularly rural women [53]. Moreover, it is important for different stakeholders like the government, civil society and the private sector to create capacity building opportunities to empower women poultry producers in enhancing their knowledge and skills. Therefore recommending that Gambia government should develop workable adult literacy policies by allocating funds, provision of training kits, allowances for women and recruitment of facilitators. This would have direct impact on women poultry producers to improve income, knowledge and skills and quality of life ideal for rural development.

From 117 valid respondents 39 are poultry and 78 poultry and sheep for household income or $<384$ US\$. The Chi-Square test result shows business activity and income level of households. From the results obtained indicate that there is strong association between the two variables shown (Table 3). This means that, the income gain from group activity would go directly into household spending like food, school fees, medicine and other miscellaneous expenses. Therefore, to be self sufficient in household food security and poverty alleviation, policy makers should formulate policies that would have direct impact on household income. One important policy would be to create and promote more small enterprises both in urban and rural areas to reduce the problem of unemployment in the rural communities of the Gambia.

In a new development approach, to understand the dynamics of rural households have emerged in recent years. The analysis of singe production activities has been replaced by the study of household as a diversified enterprise. The rural household can be seen as a centre of different types of enterprise, including non-farm activities that will continue to play an important role in rural livelihood strategies [54]. Rural household enterprises are not limited to the agricultural sector but can be non-farm activities. A farm activity plays an important role in uplifting the income of households in many developing countries. One example is agro-enterprise development through poultry production for income generation in rural Gambia. From the results of correlation matrix (Table 4) show differences in correlation between the variables. The first point of correlation between variables are saving amount and saving time which shows -875 . Secondly, in the study area there are no formal financial banking systems where these women entrepreneurs can save their funds. The best possible way to save is to travel to eastern part or lower region of the country where there are financial banks. Moreover, these women groups also keep their own funds by putting in a village box or giving it to a renowned business trader within the community for safe keeping. However, this should not be encouraged because of high risks such as thefts, fire outbreaks, and other unforeseen circumstances. Therefore, building stronger links between the various tiers of Gambia financial system, resources could be deployed more successfully to accelerate private sector development.

The second point of correlation between variables is the income of households and saving time. From the table as household income increases the time of savings

Table 3. Cross-tabulation between business activity and income of household.

\begin{tabular}{cccccc}
\hline \multicolumn{7}{c}{ Income level of household } \\
\hline Business activity & $<384$ US\$ & $430-538$ US\$ & $576-730$ US\$ & $>923$ US\$ & Total \\
\hline Poultry & 39 & 9 & 1 & 1 & 50 \\
Poultry and sheep & 78 & 0 & 0 & 0 & 78 \\
Total & 117 & 9 & 1 & 1 & 128 \\
\hline
\end{tabular}

Note: 1 US\$ $=$ D26.

Table 4. Inter-item correlation matrix.

\begin{tabular}{ccccccc}
\hline & Production & Mortality & Group income & Household income & Saving amount & Saving time \\
\hline Production & 1.000 & 0.999 & 0.637 & 0.999 & -0.611 & 0.668 \\
Mortality & & 1.000 & -0.637 & -0.999 & -0.611 & 0.668 \\
Group income & & 1.000 & 0.637 & -0.232 & 0.238 \\
Households income & & & 1.000 & -0.611 & 0.668 \\
Saving amount & & & & 1.000 & -0.875 \\
Time of saving & & & & & 1.000 \\
\hline
\end{tabular}


will also increase showing 0.668. In Bangladesh, a project was designed for women to undertake poultry production as economic activities. Micro-credit loans were given to women entrepreneurs to start poultry production and loans were paid by weekly or monthly installments the repayment rate was 99 percent. With the increase in income, the households made substantial progress in savings. Furthermore, as production increases saving time will also increase because of commitments and other issues related to poultry production.

The third point of correlation analysis between variables is production and groups income. This means that as production increases the income of households will also increase showing 0.637 (Table 4). Another correlation from the table is group income and households' income. As income of groups increases the income of household also increases concurrently at 0.637 showing high positive correlation. The fourth point worth of mentioning is production and savings amount which shows -0.611 . Meaning that amount of savings would depend on the volume of production, and sales amount is not a direct effect of saving amount. Furthermore, mortality and savings are correlated the simple reason is that if mortality rate increases within a period of time, it would have negative effect on income, which means saving amount will be reduced showing -0.611 . From the result, income of households and saving amount are also correlated, as household income increases does not mean savings amount will also increase. This can be associated to factors like payment of school fees, family expenditure and other miscellaneous expenses which will affect the amount of savings indicating -0.611 .

The fifth point of correlation matrix is high production and high mortality rate. The interpretation of results indicates that as production increases the chances of mortality rate will also increase at 0.999 . According to literature it is always advisable for the sellers to cater $10 \%$ mortality rate for the buyer as contingency incase of mortality. The incidence of diseases and stress due to long distance would result to high mortality rate in a given stock. Furthermore, another correlation point is high production which resulted to high income level of households showing 0.999 , depending on proper and better management practices. On one hand, there is high correlation between mortality and income of households at $(-0.999)$. This relationship shows that mortality will have negative relation with income of households. In this case, income will decrease as a result of high mortality rate encountered by women groups during production.

The realities of economic growth were non-farm activities play a major role is a prerequisite for business set-up in rural communities [55]. Facilitating and stimulating profitable non-farm employment should be a concern for policy makers to give maximum support to the informal sector. Therefore, policy makers need to formulate and designed agricultural policies for small business development, extensively managed, and serving as sources of income. In this case, no high productivity gains, but a stable supply of food and income are expected [56].

The long distance between producer and consumer the more complex is the market ensuring that that broilers reach the consumers in their form, place and time desired. Producers may decide to market their produce directly to consumers or may choose from different markets to sell their produce. The premise of agro-enterprise development into poultry marketing can generate big benefits for women poultry producers. In view of this, it can provide better input services to smallholders and help them compete with larger producers. There is great potential for the women groups to enter the work force as market agents and employees along the livestock market chains. From the results (Table 5), 69.6\% of women producers indicate village market and local markets while $15 \%$ of women respondents indicate village markets. Farm gate/ local markets, farm gate and local market scored $8 \%, 4 \%$, and $3.2 \%$ respectively while none for hotel and restaurant. Most of the women groups sell broilers to the weekly market or village markets within their jurisdictions. This is attributed to long distance from the nearest markets. Small quantities of chickens offered for sale restrict most farmers to take advantage of such market opportunities.

Weight is a determinant characteristic for selling live broilers. This would depend on the type of feed, the breed type and treatment would determine the weight of each layer. The research finding proves it very important to discuss about the price per $\mathrm{kg}$ of broilers produced by different women groups. From the results (Table 6) show that the price for 1 kilogram package is the best selling price for the producer. In terms of price per $1 \mathrm{~kg}$ is more rational, even the unit cost of production is the same with 2 kilogram and 1.5 kilogram. Furthermore, at 1 kilogram the meat of the chicken will be more soft and tender for consumer preference, thereby reducing the time of cooking. However, for the consumer the best price is $2 \mathrm{~kg}$. According to [57], the price of imported frozen whole chicken was D70.83 or US\$2.72 per $\mathrm{kg}$ and from this research result shows that these women groups can sell at D77.33 or US\$ 2.97 per $\mathrm{kg}$ in the local markets. This means that consumers prefer more of live broilers than imported frozen chicken meat due to taste and freshness. The 3 different packages are significantly different from one another and have been proven statistically from the research results.

In any business activity setting price is vital for an enterprise to flourish. Pricing mechanism is difficult to determine especially if producers are supplying the same market in the rural communities. It would be rather dif- 
Table 5. Marketing channels.

\begin{tabular}{ccc}
\hline Different markets & No of respondents & Percentage (\%) \\
\hline Village/local market & 128 & 69.4 \\
Village market & 128 & 15.2 \\
Farm gate & 128 & 8.0 \\
Local market & 128 & 4.0 \\
Farm gate/local market & 128 & 3.2 \\
\hline
\end{tabular}

Table 6. Price per kilogram of different broiler package.

\begin{tabular}{cc}
\hline Package & Price per kg (Mean \pm SD) \\
\hline $2 \mathrm{~kg}$ & $67.18 \pm 10.74^{\mathrm{c}}$ \\
$1.5 \mathrm{~kg}$ & $71.58 \pm 9.64^{\mathrm{b}}$ \\
$1 \mathrm{~kg}$ & $77.33 \pm 10.69^{\mathrm{a}}$ \\
\hline
\end{tabular}

Note: Different letters in the same column means significantly different at $\mathrm{p}$ $<0.05$.

ficult to have a static price in a commodity market due to market forces of demand and supply. Hence, these women groups would have different pricing mechanism within the same region. From the results (Table 7) show that Boiram women groups sells their broilers for US\$ 5.76 while Fullabantang, Gallehmanda, and Murtabeh women groups sell at US\$ 4.80 per broilers with a margin of US\$ 0.96. For the case of Boiram, the women group are opportune to have extension agent who gives technical advice by pegging selling price basing on prevailing market conditions. In addition, Boiram serving as catchment village surrounded by other villages buy broilers at a price reasonable for the villagers. In Sinchualagi the selling price for broilers is quite different from other women groups. The group sells at US\$ 4.61 per broiler at village level.

However, a difficulty in transportation due to several kilometers from the weekly market makes it extremely hard for the women to visit the market. Hence, the women would prefer selling at village market. From the research findings, the lowest price offered for sale is US\$ 3.84. However, Brikamaba women group faces the problem of market competition because of the weekly market. Buyers and sellers from different areas of The Gambia converge every Saturday to sell their produce at the weekly market. From his research findings the price of live broilers from commercial sector was D96.15 or US\$ 3.69 while the results showed the minimum or lowest price offered for sale by women groups is D99.84 or US\$ 3.84. On one hand, with better mechanism of information dissemination among the groups can realize dandy profit from poultry production enterprise.

In The Gambia, the minimum price for broilers at rural communities is US\$3.84 an additional price above this level would depend on weight $(\mathrm{kg})$ of broilers, bargaining power and negotiation skills of the group. In such a market situation, the most successful agro-entrepreneurs would be the group that produce quality product, peg better price and, add value to primary commodities to maximize profit. An enterprise is "profitable" when it produces more money or income than it spends. It is advisable prior investing money in agro-enterprise for income generating activity, the group need to calculate whether the cash they want to spend will cover their start-up and operating costs, and leave some profit for re-investment to keep the business growing [58]. Moreover, it can be quiet interesting to research on household and individual profit numbers, but this particular research only focuses on group profit. Agro-enterprise development advocates for group orientation so that, the profit gain can be ploughed back into the business or deposit into the village banks to generate more income. Moreover, the individual members can have certain percentage from the profit and the income is directly injected into household to make ends meet. In addition, the rearing period for the broilers is 8 to 20 weeks which is more cost effective than rearing of layers which usually takes a period of 6 months.

In addition, from the livestock officer view point in the study area indicate that these groups do not buy specific quantity of broilers from Senegal, but it depends on how much they can purchase at a time. He further stated that these women groups or entrepreneurs can buy broilers 2 3 times in a year. The result from (Table 7) shows that, Boiram women group scored a total profit of US\$ 1417 followed by Sinchumadado, Fullabantang, Gallehmanda and Murtabeh of US\$ 1179 and the lowest profit is US\$ 939 scored by Brikamaba respectively. The result from correlation matrix has proven that as group income increases households' income will also increase. However, from the data analysis most of the women entrepreneurs indicate US\$ 769 and US\$ 384 for group income and households' income per annum. However, results proved that minimum group income per annum is US\$ 937. According to [59] flock size is related to the objectives of the poultry enterprise. Therefore, innovative business management and marketing skills, farm accounting, record keeping, planning, organizing, coordinating and controlling of resources will enhance the success of agroentrepreneurship in the rural communities of Gambia. This kind of intervention in the rural communities will serve as a tool for poverty alleviation, create job opportunities, and increase income to improve new livelihood for sustainable human development [60].

In agro-enterprise or small and medium enterprise for income generating activity price prediction is very necessary in a business setup. Women engaged in a business 
Table 7. Production cost and profit margin.

\begin{tabular}{|c|c|c|c|c|c|c|c|c|}
\hline Women groups & No. of birds ${ }^{\mathrm{b}}$ & $\begin{array}{l}\text { Feed intake } \\
\text { for } 8 \mathrm{wks}^{\mathrm{a}}\end{array}$ & $\begin{array}{c}\text { Total cost } \\
\text { of feed US\$ }\end{array}$ & $\begin{array}{c}\text { Total cost of } \\
\text { vaccine US\$ }\end{array}$ & $\begin{array}{l}\text { Price/day-old } \\
\text { chick US\$ }^{\mathrm{a}}\end{array}$ & $\begin{array}{c}\text { Price/bird } \\
\text { US\$ }^{\mathrm{b}}\end{array}$ & $\begin{array}{c}\text { Total sales } \\
\text { US\$ }^{\mathrm{b}}\end{array}$ & Profit US\$ ${ }^{c}$ \\
\hline Sinchu-Madado & 250 & $61.87 \mathrm{~kg}$ & 19.03 & 2.40 & 0.96 & 4.80 & 1200 & 1178 \\
\hline Boiram & 250 & $61.87 \mathrm{~kg}$ & 19.03 & 2.40 & 0.96 & 5.76 & 1440 & 1418 \\
\hline Fulla-Bantang & 250 & $61.87 \mathrm{~kg}$ & 19.03 & 2.40 & 0.96 & 4.80 & 1200 & 1178 \\
\hline Sinchu-Alagi & 250 & $61.87 \mathrm{~kg}$ & 19.03 & 2.40 & 0.96 & 4.61 & 1152 & 1130 \\
\hline Brikamaba & 250 & $61.87 \mathrm{~kg}$ & 19.03 & 2.40 & 0.96 & 3.84 & 960 & 938 \\
\hline Galleh Manda & 250 & $61.87 \mathrm{~kg}$ & 19.03 & 2.40 & 0.96 & 4.80 & 1200 & 1178 \\
\hline Murtabeh & 250 & $61.87 \mathrm{~kg}$ & 19.03 & 2.40 & 0.96 & 4.80 & 1200 & 1178 \\
\hline
\end{tabular}

D26 = US\$1; Feed cost-D8/1 kg feed-US $\$=0.3 ;$ Vaccine cost-25 butut/broiler $=$ US\$ 0.010; 20 butut/layer $=$ US\$ 0.007; Day-old-chick-D25 = US\$ 0.010.

activity need to know price level of raw materials and finished product at different markets such as wholesale and retail, and regarded as business knowledge [61]. Women need to establish marketing links to sell their products and to buy raw materials to maintain the business flow. In marketing mix, product, positioning and promotion incur cost except price which brings about profit; therefore price prediction would be a vital tool to market feasibility study. The results in Figure 3 show from regression correlation showed price prediction between 3 pairs of 2 kilogram, 1.5 kilogram, and 1 kilogram of broilers. The results show regression correlation of 2 and 1.5 kilogram is the best price prediction ranging from D75 to D150 with a coefficient of determination $\mathrm{R}^{2}=0.730$.

Training is an important instrument for sound economic growth and sustainable development both developed and developing nations. Training needs is the act of acquiring skills, knowledge and attitude an individual requires in overcoming problems as well as avoiding or creating problem situations. From the result in (Table 8) shows that many of the women groups in the study area indicate group management and marketing skills as major training needs except Fullabantang whose area of training need is production technologies. The group prefers acquainting themselves with production and management skills. In terms of production the women farmers are better equipped than business related skills causing some difficulties for the women entrepreneurs; the result proves the areas of training needs eluded by the women groups. The training modules can be on production planning, pricing, market planning, negotiation skills and record keeping, farm accounting and other related business management skills.

However, the cost of training was not examined, but for such training programmes is usually funded by the governments, donor agencies or NGOs and sometimes it is free of charge. The intervention need from the stakeholder as indicated by the women includes provision of credit facilities, financial assistance and link to markets.
For women groups or entrepreneur to be successful in market place, rural women need to adopt new technologies, access information, and gain new enterprise skills so that they are in a position to evaluate and invest in new opportunities as they arise. Access to training programs, credit facilities and communication facilities would improve the knowledge and skills of these women groups. The idea of farmers' business school would serve as a catalyst to bridge the gap in areas where training is more necessary for business development. Therefore, the promotion and development of women producer groups as the basis for self-sufficiency should be supported through training (technical and business management) and startup capital in the form of goods and services. Involvement and support from the private sector in the provision of goods and services needs to be encouraged for sustainability.

Primarily, environmental assessment of the poultry production is challenging for sustainable economic growth and development. Special focus was given to health and environmental aspects of poultry rearing, including the housing and diseases of both humans and poultry, the surrounding environment, access to and sources of water, waste management, common property resources, and social conflicts related to the poultry programme. Poultry rearing can be a promising incomegenerating activity for women group. There are generic problems associated to poultry production and marketing in The Gambia. From the result (Table 9) many problems have been encountered by women entrepreneurs, but the most salient are roofing, lack of vaccine, mortality, low price and diseases which are 53\%, 50\%, 33\%, $36 \%$ and $28 \%$ respectively. Moreover, for the case of diseases, proper sanitary measures and management would be ideal step to prevent or reduce the outbreak of diseases at farm level. Furthermore, the most striking problem in relation to poultry production is high mortality rate of $80 \%-90 \%$ of production. Traditionally, Newcastle disease is believed to be the most devastating dis- 
Table 8. Training needs by women groups.

\begin{tabular}{cccccc}
\hline Women groups & No of respondents & $\begin{array}{c}\text { Group } \\
\text { management skills }\end{array}$ & Marketing skills & $\begin{array}{c}\text { Farm management } \\
\text { practices }\end{array}$ & $\begin{array}{c}\text { Production } \\
\text { technologies }\end{array}$ \\
\hline Sinchumamado & 42 & $98 \%$ & $90 \%$ & $5 \%$ & $3 \%$ \\
Boiram & 34 & $100 \%$ & $88 \%$ & $9 \%$ & - \\
Fullabantang & 13 & $54 \%$ & $8 \%$ & $80 \%$ & $92 \%$ \\
Sinchualagi & 5 & $60 \%$ & $100 \%$ & $11 \%$ & $40 \%$ \\
Brikamaba & 9 & $100 \%$ & $78 \%$ & $43 \%$ & $11 \%$ \\
Gallehmanda & 7 & $29 \%$ & - & & $29 \%$ \\
\hline
\end{tabular}

Table 9. Problems associated to poultry production.

\begin{tabular}{|c|c|c|c|c|}
\hline Housing & Vaccine & Day-old chicks & Marketing & Diseases \\
\hline Roofing (53\%) & Lack $(50 \%)$ & $\operatorname{Cost}(27 \%)$ & Competition (33\%) & Newcastle (28\%) \\
\hline Building materials (45\%) & Quality (16\%) & Sanitary measures (4\%) & Low price $(36 \%)$ & Gumboro (23\%) \\
\hline \multirow[t]{4}{*}{ Cooling system (2\%) } & Time $(16 \%)$ & Mortality (33\%) & Bargaining power $(16 \%)$ & Coccidiosis $(23 \%)$ \\
\hline & High price $(18 \%)$ & Transportation (20\%) & Market information (14\%) & Paralysis $(25 \%)$ \\
\hline & & Feeds $15 \%$ & & Control $(0 \%)$ \\
\hline & & Hatchery $(0.4 \%)$ & & \\
\hline
\end{tabular}

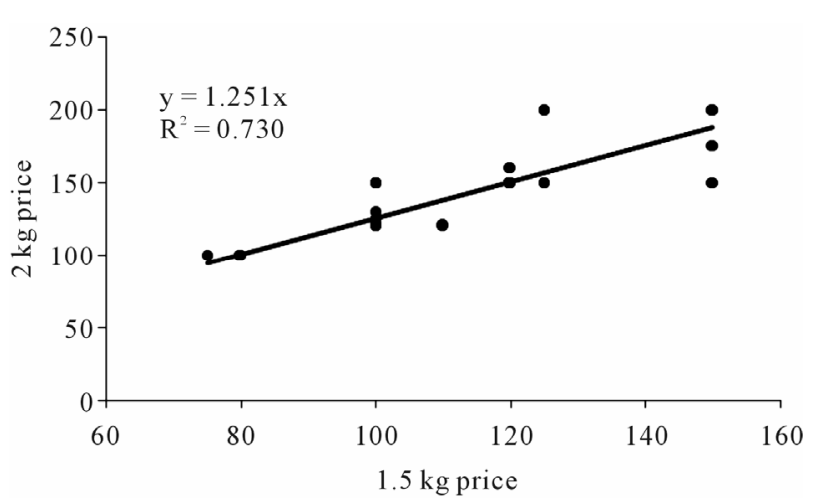

Figure 3. Price prediction between 2 kilogram and 1.5 kilogram of broiler.

ease in poultry production and the main course of high mortality. However, if vaccine against Newcastle disease [ND] cannot be delivered on time according to agreed schedules, small-scale poultry production would be difficult to succeed at rural communities [62].

Furthermore, studies in Nigeria estimated that the overall flock mortality may be as high as $90 \%$ in some areas. The marketing aspects are important when dealing with poultry production as an income generating activity. Fortunately, most studies on marketing aspects show no saturation for indigenous products on local or even national level, whereas production of improved meat (broilers) or eggs needs more attention on national and even global markets. The low marketable output gener- ates limitations to explore other distant but rewarding markets due to high transaction cost arises from soaring transportation fees and time. Consequently, chicken are sold within the villages where market outlets tend to be limited and trader cartels erode their bargaining power. From the research result the women producers indicate low price as another major problem. The market price is a tool through which they can determine what and how much is produced from the paucity resources used in production and how products can be distributed. Moreover, access to input and output markets by rural women need to be improved, so that they can be assured of reasonable prices from wide range of products [63].

Therefore, as business service provider, it is imperative to stress when dealing with women engaged in poultry production as means of addressing poverty, the risk involve in starting up or improving the production has to be minimal from producer point of view. Introducing new high yielding breeds should be done in a careful step wise manner ensuring that producers know how to handle diseases and management problems.

\section{Conclusions}

In order to accomplish a laudable goals and objectives it is important to pay attention to the development of agrowomen entrepreneurs for income generating activity in Central River Region of rural Gambia. With this approach, they can take their role in family engagements 
and national economic development. The government and development change agents must not only be prepared to recognize the economic role of women but design policies that would directly affect the lives of women agro-entrepreneurs in rural communities. The most important relationship with other research findings is the act of information dissemination and theoretical understanding of innovations to the end-users. Furthermore, the implication of this research work would be the transfer of knowledge to the rural communities as beneficiaries of innovation for better understanding, increasing of income and improving standard of living.

In the process of training, extension agents can interact with women producers for learning and sharing of knowledge, so that women can have opportunities to acquire technical skills and practice business related strategies. This approach would be replicated to other women groups who want to start poultry production as a business in other regions of The Gambia. The government, donor agencies and NGOs can use this information to understand effectiveness of agro-enterprise as income generating activity. These will help stakeholders in their fight to reduce poverty, increase income and improve the livelihood of rural women. The information obtained from this study will further assist the stakeholders to have better understanding of the obstacles and problems faced by rural women to increase their productivity. The women groups can increase productivity, if they have access to land and recognized beneficiaries of land acquisition.

In addition, access to land is indeed the most empowering step in the right direction to gender equity. The goal of gender equity will be more ideal and workable by equal land ownership for agro-enterprise promotion and development. Success of small income generating activity such as poultry and livestock should not detract from demanding equal division of land and inherited property among women and men. In addressing the objectives of this research findings like assessing the income, training needs and problem solving we conclude that poultry production enterprise can play a meaningful role in poverty reduction, generate income, and create employment opportunities to improve the living standard in enhancing the growth of rural economy rural. Therefore, it is recommended for policy makers to design policies geared towards adult literacy programmes or establishment of business school concept. This would help the women entrepreneurs to acquire knowledge and skills on small business development in support of their income generating activities.

\section{Acknowledgements}

This piece of work is dedicated to my beloved wife Kumba Jayfang Sanyang and my children Omar Sanyang and Khadija Sanyang for their kindness while undergoing this research work. I wish to acknowledge my Professor Wen-Chi Huang for her valuable and critical contributions in order to improve the quality of this research work. Sincere appreciation and dedication to the family of Sanyang Kunda. Special thanks to my caring mother for her words of encouragement during my academic endeavors.

\section{REFERENCES}

[1] Food and Agriculture Organization, "Gender Key to Sustainability and Food Security. Plan of Action. Gender and Development," Journal of Rural Studies, Vol. 15, 2003, pp. 147-158.

[2] D. Peters, "Small-Scale Agro-Enterprise Development for the Uplands of Vietnam and Laos Progress Report February-September," 2004, p. 120.

[3] M. E. Chavez, "Cooperatives: Rural Development and Decent Work," Paper Presented at the ECOSCO Ministerial Round Table, Increasing Productivity of Rural Work, 2003.

[4] D. M. Akpera and M. Sunday, "Strategies for the Development of Entrepreneurs in Nigeria," A Paper Presented at the 3-Day International Workshop on "Promoting Entrepreneurship Education among Nigeria Women: Issues and Approaches," Abuja, 2008, 12 Pages.

[5] P. Robbins, R. S. B. U. Kleih and F. Bikande, "A Guide to Collective Marketing for Small-Scale Producers," Association for Strengthening Agricultural Research in Eastern and Central Africa, Monograph, 2005.

[6] R. S. B. Ferris, R. Best, M. C. Lundy, M. V. Ostertag and T. Wandsschaneider, "Strategy Paper: A Participatory and Area-Based Approach to Rural Agro Enterprise Development," Rural Agro Enterprise Development Project, Centro International de Agricultura Tropical (International Center for Tropical Agriculture), Cali, 2006, p. 44.

[7] G. Dixie, "Horticultural Marketing FAO Marketing Extension Guide," Rome, 2005.

[8] Organization for Economic Development and Cooperation Promoting Entrepreneurship and Innovative SMEs in a Global Economy, "Towards for a More Responsive and Inclusive Globalization," Proceedings of OECD Conference on Women's Entreprenership: Issue and Policies, Istanbul, 2004.

[9] M. Lundy, M. V. Gottret, W. Cifuentes, C. F. Ostertag, R. Best, S. Ferris and D. Peters, "Design of Strategies to Increase the Competitiveness of Smallholder Chains, Rural Agro Enterprise Development Project," International Center for Tropical Agriculture, Cali, 2004.

[10] C. C. Wheatley, "Improving Local Support for Agro Enterprises in Yorito and Sulaco, Honduras and Caldono, Colombia: Phase 1 Progress Report to NZAID," International Center for Tropical Agriculture, Cali, 2003.

[11] C. F. Ostertag, "Identifying and Assessing Market Opportunities for Small Rural Producers. Series: Tools for Decision-Making in Natural Resource Management," Cali, 
2006, p. 264.

[12] T. Reardon, J. Berdegue and G. Escobar, "Rural NonFarm Employment and Incomes in Latin America: Overview of Issues, Patterns and Determinants," World Development, Vol. 29, No. 3, 2001, pp. 395-409. doi:10.1016/S0305-750X(00)00112-1

[13] A. W. Shepherd, "Market Research for Agro-Processors. FAO Marketing Extension Guide," Food and Agriculture Organization of the United Nations (FAO), Italy, 2003.

[14] D. Kuratko, F. Richardand and M. Hodgetts, "Entrepreneurship a Contemporary Approach," Harecourt College Publishers, New York, 2001.

[15] P. Sanginga and C. Chitsike, "The Power of Visioning. A Handbook for Facilitating the Development of Community Action Plans. Enabling Rural Innovation in Africa Guide No. 1," International Center for Tropical Agriculture, Kampala, 2005, p. 134.

[16] A. Rottger, "Strengthening Farm-Agribusiness Linkages in Africa. Proceedings of Expert Consultation, Nairobi, 23-17 March 2003. AGSR Working Document 5. Agricultural Management, Marketing and Finance Service (AGSF). Agricultural Support Systems Division," Food and Agriculture Organization of the United Nations, Rome, 2004.

[17] T. Asefa, "Poultry Management Practices and on Farm Performance Evaluation of Rhode Island Red (RIR), Fayoumi and Local Chicken in Umbullo Wachu," Department of Animal and Range Sciences, Hawassa College of Agriculture, Awassa, 2007.

[18] P. Santacolomba and H. Riveros, "Alternatives to Improve Negotiation and Market Access Capabilities of Small-Scale Rural Entrepreneurs in Latin America. AGSR Working Document 4. Agricultural Management, Marketing and Finance service (AGSF). Agricultural Support Systems Division," Food and Agriculture Organization of the United Nations, Rome, 2004.

[19] R. Best, "Farmer Participation in Market Research to Identify Income-Generating Opportunities. Centro Internacional de Agricultura Tropical (International Center for Tropical Agriculture)," Kampala, 2003, p. 2. www.International Center for Tropical Agriculture.cgiar.org/

[20] D. Giovannucci, "Organic Agriculture and Poverty Reduction in Asia: China and India Focus," Office Evaluation, International Fund for Agricultural Development, Rome, 2005.

[21] A. S. Suleiman, "The Business Entrepreneur; Entrepreneurial Development, Small and Medium Enterprises," 2nd Edition, Entrepreneurship Academy Publishing, Kaduna, 2006.

[22] R. Nyapendi, E. R. KaganziBest and B. R. S. Ferris, "Identifying and Assessing Market Opportunities in Kampala for Smallholder Farmers in Uganda," The NARO INRM Conference, Entebbe, 1-4 September 2004.

[23] G. T. Olutunla, "Policy Framework and Strategy for Entrepreneurship Development of Nigerian Women," The 3-Day International Workshop on "Promoting Entrepreneurship Education amongst Nigerian Women: Issues and Approaches," Abuja, 2008, 15 Pages.
[24] Food and Agriculture Organization, "Livestock for Food, Income, Employment and Sustainable Agriculture," Animal Production and Health Division, Rome, 2002.

[25] S. Premchander, "Impact of Micro-Finance on Women's Livelihoods," Asian Society for Entrepreneurship Education and Development, 2000, pp. 362-363.

[26] J. Sumner, "Visions of Sustainability: Women Organic Farmers and Rural Development," Canadian Women Studies, 2003.

[27] J. H. Fraslin, "A Cooperative Agricultural Financial Institution Providing Credit Adopted to Farmers' Deman in Madagascar," Paving the Way forward for Rural Finance, an International Conference on Best practices. Case Study, BASIS-Broadening Access and Strengthening Input Market Systems, Madison, 2004.

[28] A. Hyytinen and M. Pajarinen, "Financing of Technology-Intensive Small Businesses: Some Evidence on the Uniqueness of the ICT Sector," Information Economics and Policy, Vol. 17, No. 1, 2005, pp. 115-132. doi:10.1016/j.infoecopol.2004.03.005

[29] J. T Scott, “An Assessment of the Small Business Innovation Research Program in New England: Fast Track Compared with Non-Fast Track Projects," In: C. W. Wessner, Ed., The Small Business Innovation Research Program: An Assessment of the Department of Defense Fast Track Initiative, National Academy Press, Washington DC, 2000, pp. 104-140.

[30] J. C. Riise, A. Permin, C. E. S. Larsen and A. Idi, "Optimizing Appropriate Technology Transfer to Small Producers," Wireless Power Consortium, Istanbul, 2004.

[31] C. Peacock, A. Jowett, A. Dorwar, C. Poulton and I. Urey, "Reaching the Poor, a Call to Action. Investment in Smallholder Agriculture in Sub-Saharan," FARM-Africa, London, 2004, p. 30.

[32] Y. Muhammed, "An Empirical Investigation of Rationing Constraints in rural Credit Markets in India," Journal of Development Economics, Vol. 53, No. 2, 2003, pp. 339371.

[33] S. Sinha, "Developing Women's Entrepreneurship in South Asia: Issues Initiatives and Experiences," UNESCAP, Bangkok, 2005.

[34] C. U. Gminder, "Gender-Oriented Entrepreneurship Promotion: Strategies and Tools along the Project Cycle, a Manual for Practitioners, Part II Toolkit," The Swiss Agency for Development and Cooperation, Bern, 2003.

[35] J. T. Scott, "The Directions for Technological Change: Alternative Economic Majorities and Opportunity Costs," Review of Industrial Organization, Vol. 17, No. 1, 2000, pp. 1-16. doi:10.1023/A:1007875415472

[36] P. A. T. Aboe, E. A. Butler, P. T. Dorward and M. J. Bryant, "Free-Range Village Chickens on the Accra Plains," Ghana: Husbandry and Productivity Tropical Animal Health and Production, Vol. 38, 2006, pp. 223-224.

[37] J. Hellin, A. Griffith and A. Mike, "Mapping the Market: Market-Literacy for Agricultural Research and Policy to Tackle Poverty in Africa beyond Agriculture Making Markets Work for the Poor," Proceedings on an International Seminar, Westminister, London, 28 February-1 
March 2005, pp. 110-150

[38] G. Holloway and S. Ehui, "Expanding Market Participation among Smallholder Livestock Producers (SocioEconomic and Policy Research Working Paper 48)," International Livestock Research Institute, Nairobi, 2002.

[39] I. G. S, Budiastra, H. M. J. Udo, A. Murti and E. Bailiarti, "Religious Festivities and Supply and Demand of Small Poultry in Central Java, Indonesia, Animal Production Systems," Wageningen University, Wageningen, 2006.

[40] S. Haggblade, P. Hazell and T. Reardon), "Strategies for Stimulating Poverty Alleviating Growth in the Rural Nonfarm Economy in Developing Countries," World Bank, International Food Policy Research Institute, Washington DC, 2002.

[41] D. B. Audretsch and J. Weigand, "Do Knowledge Conditions Make a Difference? Investment, Finance and Ownership in German Industries," Research Policy, Vol. 34, No. 5, 2005, pp. 595-613. doi:10.1016/j.respol.2004.12.004

[42] M. S. Freel, "Are Small Innovators Credit Rationed?" Small Business Economics, Vol. 28, No. 1, 2007, pp. 2335. doi:10.1007/s11187-005-6058-6

[43] E. Gueye, "The Role of Family Poultry in Poverty Alleviation, Food Security and the Promotion of Gender Equality in Rural Africa," Outlook on Agriculture, Vol. 29, No. 2, 2002, pp. 129-136.

[44] S. N., Meera, A. Jhamtani and D. U. M Rao, "Information and Communication Technology in Agricultural Development: A Cooperative Analysis of Three Projects from India," 2004. p. 135.

[45] A. Barua and Y. Yoshimura, "Rural Poultry Keeping in Bangladesh," World's Poultry Science Journal, Vol. 53, 2005, pp. 387-394. doi:10.1079/WPS19970031

[46] W. Marlyin, "Gender Issues in Macro-Economic Policy Planning for Agricultural and Rural Development: Imperative for the 21st Century, in Gender Issues in Agricultural Policy in Asia and Pacific," Regional Office for Asia and the Pacific, Bangkok, 2005.

[47] J. Davis and C. Rylance, “Addressing Poverty through Local Economic and Enterprise Development. A Review of Conceptual Approaches and Practice," Working Paper Chatham Natural Resources Institute, Kent, 2005.

[48] J. Rushtonand and S. Ngongi, "Poultry Women and Development: Old Ideas, New Applications and Need for Research," Department of Agriculture, University of Reading, Reading, 2002.

[49] H. C. Haan, "Business networking for Small and Medium Enterprise Development in the United Arab Emirates," 2004.

[50] M. Pedener, "Entrepreneurial Competition and Industrial Location: Investigating the Structural Patterns and Intangible Sources of Competition Performance," Edward El- gar, Cheltenham and Northampton, 2001.

[51] F. Lesby, "Promoting Commercially Viable Solutions to Sub-Sector and Business Constraints," Presentation of Action for Enterprise, Food and Agriculture Organization, Rome, 2005.

[52] J. O. Oladeji, M. G. Olujide and O. B. Oyesola, "Income Generating Activities of Fulani Women in Iseyin Local Government Area of Oyo State," Journal of Study, Tribes, Vol. 4, No. 2, 2006, pp. 117-121.

[53] H. C. Haan, "Fingers of One Hand," Experiences of Small Business in the Northern Emirates, Dubai, 2003.

[54] C. B. Barrett, T. Reardon and P. Webb, "Non-Farm Income Diversification and Household Livelihood Strategies in Rural Africa: Concepts, Dynamics, and Policy Implications," Food Policy, Vol. 26, No. 4, 2001, pp. 315-331. doi:10.1016/S0306-9192(01)00014-8

[55] M. Fritsch, U. Brixy and O. Falck, "The Effect of Industry, Region and Time on New Business Survival a MultiDimensional Analysis," Review of Industrial Organization, Vol. 28, No. 3, 2006, pp. 285-306. doi:10.1007/s11151-006-0018-4

[56] A. Schejtman and J. Berdegue, "Rural Territorial Dynamic: A Research Based Policy Advice and Capacity-Building Programme for Rural Economic Growth and Social Inclusion," Unpublished Mimeo, 2006.

[57] M. T. Omar, "Poultry Sector Country Review of the Gambia: Food and Agriculture Organization,” 2008.

[58] F. L. Kampeni, "Smallholder Poultry Production in Malawi," Proceedings of a Workshop on Possibilities for the Smallholder Poultry Projects in Eastern and Southern Africa, Morogoro, 2000, pp. 43-46.

[59] F. Ellis, "The Determinants of Rural Livelihood Diversification in Developing Countries," Journal of Agricultural Economics, Vol. 51, No. 2, 2000, pp. 289-302. doi:10.1111/j.1477-9552.2000.tb01229.x

[60] V. Hartarska and C. Gonzalez-Vega, "What Affects New and Established Firms' Expansion? Evidence from Small Firms in Russia," Small Business Economics, Vol. 27, No. 2-3, 2006, pp. 195-206. doi:10.1007/s11187-006-0012-0

[61] E. Lehmann, D. Neuberger and S. Rathke, "Lending to Small and Medium-Sized Firms: Is There an East-West Gap in Germany?" Small Business Economics, Vol. 23, No. 23, 2004, pp. 23-39. doi:10.1023/B:SBEJ.0000026024.55982.3d

[62] R. Alders, F. DosAnjos, B. Bagnol, A. Fumo, B. Mata, and M. Young, "Controlling Newcastle Disease in Village Chickens: A Training Manual,” 2000, p. 128.

[63] J. Kusina and J. Mhlanga, "Smallholder Poultry Production in Malawi," Proceedings of a Workshop on Possibilities for the Smallholder Poultry Projects in Eastern and Southern Africa, Morogoro, 2000, pp. 51-61. 